Zagazig J. Agric. Res., Vol. 46 No. (6A) 2019

http:/www.journals.zu.edu.eg/journalDisplay.aspx?Journalld=1\&queryType=Master

\title{
PERFORMANCE AND GENE ACTION FOR EARLINESS, YIELD AND CHOCOLATE SPOT DISEASE OF FABA BEAN
}

\author{
Mostafa G. El-Abssi*, H.A. Rabi, H.A. Awaad and Naglaa Qabil \\ Agron. Dept., Fac. Agric., Zagazig Univ., Egypt
}

Received: 01/08/2019 ; Accepted: 01/09/2019

\begin{abstract}
In order to determine performance, gene action and heritability for earliness, yield and chocolate spot disease of faba bean, a half diallel crosses among six parental genotypes were evaluated under control and artificial infection by chocolate spot disease (Botrytis fabae sard). The results indicated highly significant differences among faba bean genotypes for all the studied characters under these conditions. All faba bean genotypes under study appeared to be high resistant or resistant for chocolate spot disease with a few exception under different conditions. Whereas, genotypes Misr 3, Wadi 1, Sakha 4 x Misr 3, Sakha 4 x Nubaria 1, and Misr 3 x Wadi 1 under the natural infection conditions. However, Sakha 4, Nubaria 1, NA 112, Sakha 4 x Misr 3, Sakha 4 x NA 112, Misr 3 x Wadi 1, Nubaria 1 x T.W, Wadi 1 x NA 112 and T.W x NA 112 under the artificial infection were less resistant or susceptible to chocolate spot disease. The results revealed that additive (D) and dominance $\left(\mathrm{H}_{1}\right.$ and $\left.\mathrm{H}_{2}\right)$ appeared to be significant for days to flowering and maturity, chlorophyll content (SPAD), seed weight/plant and resistance to chocolate spot under both conditions. The additive genetic component was higher in its magnitude as compared to the dominance ones for resistance to chocolate spot under the natural infection condition, resulting in average degree of dominance $\left(\mathrm{H}_{1} / \mathrm{D}\right)^{0.5}$ less than the unity. Whereas, dominance component $\left(\mathrm{H}_{1}\right.$ and $\left.\mathrm{H}_{2}\right)$ made up the most part of the total genetic variation as it was larger in its magnitude than the corresponding additive one for earliness characters, chlorophyll content and seed weight/plant under both conditions and resistance to chocolate spot under the artificial infection only. Thus, the average degree $\left(\mathrm{H}_{1} / \mathrm{D}\right){ }^{0.5}$ was more than the unity for these characters. Narrow sense heritability $\left(\mathrm{h}^{2}{ }_{\mathrm{n}}\right)$ was moderate $(39.1 \%)$ to low $(20.4 \%)$ for seed weight/plant and high $(65.1 \%)$ to moderate $(45.0 \%)$ for chocolate spot disease under control, natural infection and artificial infection of chocolate spot disease, respectively.
\end{abstract}

Key words: Artificial infection, chocolate spot, diallel, faba bean, narrow sense heritability.

\section{INTRODUCTION}

Faba bean (Vicia faba L.) is one of the most important seed legumes in the Arabian regions of North and East Africa, especially in Egypt. It play an important role in world agriculture, owing to its high protein content, ability to fix atmospheric nitrogen, capacity to grow and yield well on marginal lands (Al-Ghamdi, 2007). Improvement of earliness, high yield and disease resistance potential are the primary objectives of faba bean breeding programs. An understanding of the fundamental nature of the actions and interactions of genes involved in the inheritance of quantitative characters is very helpful to plant breeders in their evaluation of various selection and breeding procedure. The breeding system needs to be fitted to the type of gene action to maximize the result of improvement. In Egypt, the cultivated area in 2017 reached to 77426 faddan with an average productivity 9.4 ardab/ faddan. While, the total area in the world was 5864239 faddan with an average productivity $5.32 \mathrm{ardab} /$ faddan (FAO, 2018)

Chocolate spot (Botrjytis fabae Sard) is considered of the most destructive diseases and causes considerable losses in faba bean yield in North Delta region of Egypt, particularly during

\footnotetext{
*Corresponding author: Tel. : +201065196737

E-mail address: mostafaelabsy2@gamil.com
} 


\section{El-Abssi, et al.}

wet seasons where low temperature and high relative humidity favour its spread and severity. Affected plants usually have fewer pods which reduces their yield potential. In unprotected crops the disease can be expected to reduce yields by $30-50$ percent in a bad conditions. In addition, seeds from badly affected plants may have a reddish-brown discoloration, which lowers their market value. Symptoms are varied and range from small spots on the leaves to complete blackening of the entire plant. Leaves are the main part of the plant affected, but under favorable conditions for the disease it also spreads to stems, flowers and pods. Two stages of the disease are usually recognized. First, a non-aggressive phase, when discrete reddishbrown spots are 'peppered' over the leaves and stems. Next, an aggressive phase occurs when spots darken in colour and coalesce to form larger grey-brown target spots that may eventually cover the entire plant. Small black sclerotia may sometimes be found inside the stems of badly diseased plants Crop Pro (2019).

Diallel analysis technique developed by Hayman (1954 a and b) and Jinks (1954) was used in the evaluation of parents and crosses, hence it gives as early as in $F_{1}$ generation. The amount of heterosis shown by a hybrid depends largely on the genetic divergence of the parental genotypes.

A successful breeding program depends upon the information on the genetic variability and gene action controlling yield and its attributes. Attia and Salem (2006) reported that additive and dominance genetic effects were significant for all studied traits i.e. days to flowering, seed yield/ plant and 100 seed weight. Ibrahim (2010), Obiadalla-Ali et al. (2013) and Bishnoi et al. (2018) showed that non-additive gene action were important in governing the genetic system of yield and its attributes. Moreover, Abo-Mostafa et al. (2014) and Beyene et al. (2016) indicated that additive gene action played an important role in the inheritance of resistance to chocolate spot. Otherwise, information about heritability is important in predicting the expected genetic gain from selection in faba bean populations. In this connection, estimates of heritability in narrow sense for days to flowering, days to maturity and seed yield were reported by many investigators (El-Galaly $\boldsymbol{e t} \boldsymbol{a l}$.,
2009; Ibrahim, 2010; Obiadalla-Ali et al., 2013).

The present investigation aimed to study the mean performance, gene action and heritability for earliness characters and seed yield under the natural and artificial infection of chocolate spot disease.

\section{MATERIALS AND METHODS}

The present investigation was performed at the two winter growing seasons of 2017/2018 and 2018/2019. Six parental genotypes of faba bean were selected based on the presence of wide differences among them. The used genotypes in this study were obtained from Agriculture Research Center, Field Crop Research Institute, Egypt. Pedigree and origin of parental faba bean genotypes involved in diallel cross are given in Table 1. The selected parents were crossed in a half diallel scheme to obtain all possible combinations, excluding reciprocals during the first season of 2017/2018 giving total of $15 \mathrm{~F}_{1}$ 's seeds under insect free cages conditions. The parents and their respective $F_{1}$ crosses were planted under field condition in two experiments during the second growing season of 2018/2019.

\section{Mating Design and Experimental Layout}

\section{Evaluation of parents and $F_{1}{ }^{6} s$}

In 2017/2018 winter growing season, six parental faba bean genotypes were grown under two sowing dates 22/10/2018 and 7/11/2018 at the Experimental Farm, Faculty of Agriculture, Zagazig University, Egypt. All possible cross combinations excluding reciprocals were made among the six parental genotypes using hand emasculation and pollination in order to produce the seeds of the $15 \mathrm{~F}_{1}$ diallel cross. Crossing process was made in insect free cages to prevent the contamination of foreign pollen grain.

\section{First experiment (Control)}

In the winter growing season 2018/2019, parental genotypes and their $\mathrm{F}_{1}$ 's were sown on $3^{\text {rd }}$ November 2018 in a randomized complete block design (RCBD) with three replications at an extension field at Belbies district, Sharkia Governorate, Egypt. Each block included $15 \mathrm{~F}_{1}$ 's 
Zagazig J. Agric. Res., Vol. 46 No. (6A) 2019

Table 1. Pedigree of parental faba bean genotypes involved in diallel cross

\begin{tabular}{lccc}
\hline No. & Genotypes & Pedigree & Origin \\
\hline 1 & Sakha 4 & Sakha 1 x Giza 3 & Egypt \\
2 & Misr 3 & 667x (Cairo 241x Giza 461) & Egypt \\
3 & Nubaria 1 & Selection in Rena Blanka & Egypt \\
4 & Wadi 1 & Rena Blanka x Triple white & Egypt \\
5 & Triple white & Sudan & Sudan \\
6 & NA112 & Pakistan & Pakistan \\
\hline
\end{tabular}

crosses and their six parental genotypes. Each experimental unit consisted of 3 ridges i.e., one ridge for $\left(\mathrm{P}_{1}\right)$, one for $\left(\mathrm{P}_{2}\right)$, one ridge for $\left(\mathrm{F}_{1}\right)$. The ridge length was 3 meter, ridge to ridge spacing was $60 \mathrm{~cm}$ and plant to plant distance was $20 \mathrm{~cm}$. Seeds were planted in single seeded hills. Normal agricultural practices for faba bean production were done in both growing seasons at the proper time. Plant materials of the experiment were sprayed with Tridex super $75 \%$ WG at a rate of $200 \mathrm{~g} / 100$ liter of water on midJanuary and first of February protective spray. The experiment was irrigated as needed.

\section{Second experiment (Artificial infection) \\ Chocolate spot infection and experimental layout}

\section{Inoculum preparation}

A single-conidium isolate of (Botrytis fabae sard) was used. This isolate was previously selected as virulent among isolates obtained from a wide range of naturally infected faba bean leaves collected from Nile Delta region. One- centimeter portions from spots of infected leaves were disinfected in $1 \%$ Clorox solution for 0.5 to $1 \mathrm{~min}$, washed three times in sterile water, and dried on sterile filter paper. Cultures were maintained and sub-cultured on potato dextrose agar (PDA) in $9 \mathrm{~cm}$ Petri dishes. Then were transferred into faba bean leaf extract medium as described by Leach and Moore (1966), on which the pathogen produced a large number of conidia. After incubation for 10 days at $20-22^{\circ} \mathrm{C}$, the surface of every colony was covered with 5 to $10 \mathrm{ml}$ of sterile water. The spores were dislodged from the surface of the agar, by passing gently an elbowed Pasteur pipette (Tivoli et al., 1986). The substance obtained was filtered through two layers of sterile gauze and diluted with tap water. The spore concentration was adjusted by using a hem cytometer slide.

\section{Experimental layout and inoculation}

In the winter growing season $2018 / 2019, F_{1}$ 's were sown in a randomized complete block design (RCBD) with three replications at the extension field at Belbies district, Sharkia Governorate, Egypt. Each block included $15 \mathrm{~F}_{1}$ 's crosses and their six parental genotypes. Each experimental unit consisted of 3 ridges i.e., one ridge for $\left(\mathrm{P}_{1}\right)$, one for $\left(\mathrm{P}_{2}\right)$, one ridge for $\left(\mathrm{F}_{1}\right)$. The ridge length was 3 meter, ridge to ridge spacing was $60 \mathrm{~cm}$ and plant to plant distance was $20 \mathrm{~cm}$. Genotypes were evaluated under the artificial infection of foliar disease in Sharkia Governorate, Egypt. The check cultivar Misr 3 was inserted every three plot genotype. Also, the experiment was surrounded by belt of Misr 3 as spreader. Plants were inoculated 70 days after sowing on 13 January 2019 by spraying the foliage with 15 to $20 \mathrm{ml}$ of the inoculum per plant. The concentration of spore suspension was $3 \times 10^{5}$ spores $/ \mathrm{ml}$ (Bouhassan et al., 2004). Inoculation was performed on five plants in each ridge and covered by cages for 48 hours. The remaining plants in each ridge were leaved to natural infection. The reaction to chocolate spot (Botrytis fabae sard) in artificial infection were recorded on the first of February and first of March (2019), whereas, in natural infection was recorded 60 and 80 days after sowing according to ICDARDA scale from 1-9 (Bernier $\boldsymbol{e t}$ al., 1993) as follow:

$1=$ no disease symptoms or very small specks (Highly Resistance) 


\section{El-Abssi, et al.}

$3=$ few small discrete lesions (Resistance)

$5=$ some coalesced lesions with some defoliation (Moderate Resistance).

$7=$ large coalesced sporulating lesians50\% defoliation and some dead plant (Susceptible).

9= Extensive lesions on leaves stems and pods severe defoliation heavy sporulation stem girdling blackening and death of more than $80 \%$ of plants (Highly Susceptible)

Data were recorded on ten randomly selected plants in each genotype per replication for the following characters viz., days to flowering (day), days to maturity (day), chlorophyll content (SPAD), seed yield/plant $(\mathrm{g})$ and resistance to chocolate spot under the control conditions and artificial infection of chocolate spot disease conditions.

The data were subjected to analysis of variance technique (Steel et al. 1997). The differences among faba bean genotypes means were tested using a revised LSD test at $5 \%$ level of significant.

The reduction percentage of means due to artificial infection of chocolate spot disease for all studied traits was calculated as [(mean value of control condition trait-mean value of artificial infection condition trait)/mean value of control condition trait] x 100 .

\section{RESULTS AND DISCUSSION}

\section{Mean Performance}

The mean performances of parental genotypes and their $\mathrm{F}_{1}$ 's crosses for days to flowering, days to maturity, chlorophyll content, seed weight/ plant and resistance to chocolate spot under control, natural and artificial infection by chocolate spot disease conditions are given in Table 2 . The results indicated highly significant differences among faba bean genotypes for all the studied characters under these conditions. So, these results provide evidence for the presence of adequate amount of genetic variability valid for further biometrical assessments. AboMostafa et al. (2014), Abdalla et al. (2015), Jalal et al. (2016), Abdalla et al. (2017), AbouZaid et al. (2017) Hamza and Khalifa (2017) and Qabil et al. (2018) recorded highly significant differences among faba bean genotypes for faba bean characters.
For days to flowering under the control and the artificial infection conditions (Table 2), both faba bean parental cultivars Misr 3 and Wadi 1 as well as their respective crosses (Misr $3 \mathrm{x}$ Wadi 1) and (Misr 3 x T.W) were the earliest among the studied faba bean genotypes. Therefore, these genotypes were promising ones for earliness. Conversely, the genotype NA 112 as well as it's respective cross (T.W x NA 112) were the latest ones under the two conditions.

In continuous and as shown in Table 2, it is worthy to note that the two faba bean parental cultivars Sakha 4 and Nubaria 1 as well as $F_{1}$ crosses (Sakha 4 x T.W), (Sakha 4x NA 112), (Misr 3 x Nubaria 1) and (Misr 3 x Wadi 1) under the control and the artificial infection conditions as well as (Sakha $4 \mathrm{x}$ Misr 3) under the artificial infection one were the earliest maturity than the remaining faba bean genotypes. Whereas, the parental genotype NA 112 and $F_{1}$ crosses (Nubaria 1x Wadi 1), (Nubaria $1 \mathrm{x}$ T.W), (Wadi 1 x NA 112) and (T.W x NA 112) were the latest one under the control and the artificial infection conditions. The above results might be suggested that these crosses are of great important for isolating new genotypes with early maturity.

As seen in Table 2, results indicate that the highest concentration of chlorophyll content was registered in Sakha 4 under the control and the artificial infection conditions; Wadi 1 under the control condition as well as Nubaria 1 and NA 112 under the artificial infection one. The highest concentrations of chlorophyll content which obtained by the abovementioned parental genotypes reflected in their $F_{1}$ crosses (Sakha 4 $\mathrm{x}$ T.W), (Misr $3 \times$ Wadi 1) and (Wadi $1 \times$ NA 112) under the control condition as well as (Sakha 4 x Wadi 1), (Sakha 4 x NA 112) and (Nubaria $1 \times$ T.W) under the artificial infection one. Therefore, these genotypes could be used for selecting new recombination characterized by high concentrations of chlorophyll content. On the other hand, the faba bean parental genotypes Nubaria 1 and NA 112 under the control condition as well as Misr 3, Wadi 1 and Triple white under the artificial infection one had the lowest concentrations of chlorophyll content. Meantime, results indicated that the highest value of chlorophyll content was recorded in their $F_{1}$ (T.W x NA 112) under the two conditions. 
Zagazig J. Agric. Res., Vol. 46 No. (6A) 2019

Table 2. Mean performance of parental faba bean genotypes and their $F_{1}$ crosses for the studied characters under control, natural infection and artificial infection of chocolate spot disease conditions

\begin{tabular}{|c|c|c|c|c|c|c|c|c|c|c|c|c|}
\hline \multirow[b]{3}{*}{ Genotype } & \multicolumn{2}{|c|}{$\begin{array}{c}\text { Days to } \\
\text { flowering (day) }\end{array}$} & \multicolumn{2}{|c|}{$\begin{array}{c}\text { Days to } \\
\text { maturity (day) }\end{array}$} & \multicolumn{2}{|c|}{$\begin{array}{c}\text { Chlorophyll } \\
\text { content (SPAD) }\end{array}$} & \multicolumn{2}{|c|}{$\begin{array}{c}\text { Seed } \\
\text { weight/plant }(g)\end{array}$} & \multicolumn{4}{|c|}{ Chocolate spot disease } \\
\hline & \multirow[b]{2}{*}{ 总 } & \multirow[b]{2}{*}{ 焉 } & \multirow[b]{2}{*}{ } & \multirow[b]{2}{*}{ 焉 } & \multirow[b]{2}{*}{ 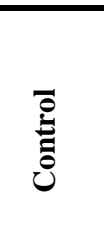 } & \multirow[b]{2}{*}{ 㺼 } & \multirow[b]{2}{*}{ 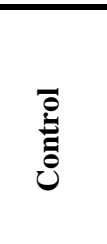 } & \multirow[b]{2}{*}{ 胥 } & \multicolumn{2}{|c|}{ Natural } & \multicolumn{2}{|c|}{ Artificial } \\
\hline & & & & & & & & & 总 & 芝 & 冚 & $\stackrel{0}{2}$ \\
\hline Sakha 4 & 43.67 & 43.67 & 152 & 152 & 48.36 & 39.13 & 154.93 & 100.37 & 3.00 & $\mathrm{R}$ & 3.00 & $\mathrm{R}$ \\
\hline Misr 3 & 41.33 & 40.33 & 155 & 151 & 41.60 & 23.93 & 111.10 & 106.97 & 7.00 & $S$ & 7.00 & $S$ \\
\hline Nubaria 1 & 68.00 & 68.00 & 154 & 154 & 36.55 & 33.37 & 101.40 & 58.50 & 3.00 & $\mathrm{R}$ & 3.50 & $\mathrm{R}$ \\
\hline Wadi 1 & 38.00 & 38.00 & 156 & 155 & 53.30 & 27.40 & 83.67 & 85.76 & 6.00 & MR-S & 5.00 & MR \\
\hline Triple white & 46.33 & 46.33 & 155 & 154 & 46.30 & 26.40 & 61.83 & 55.60 & 1.00 & HR & 5.67 & MR \\
\hline NA 112 & 88.00 & 87.33 & 163 & 161 & 35.20 & 37.40 & 10.03 & 3.59 & 1.00 & HR & 1.00 & HR \\
\hline Sakha 4 x Misr 3 & 43.00 & 43.00 & 155 & 154 & 42.65 & 39.60 & 94.57 & 87.53 & 4.00 & R-MR & 3.00 & $\mathrm{R}$ \\
\hline Sakha 4 xNubaria 1 & 46.67 & 46.67 & 156 & 155 & 38.95 & 37.27 & 159.90 & 74.47 & 4.00 & R-MR & 4.67 & MR \\
\hline Sakha 4 x Wadi 1 & 44.00 & 44.00 & 158 & 157 & 41.50 & 41.83 & 64.57 & 116.20 & 3.00 & $\mathrm{R}$ & 4.00 & R-MR \\
\hline Sakha 4 x T.W & 46.00 & 46.00 & 151 & 150 & 49.25 & 35.70 & 77.97 & 52.07 & 2.33 & HR-R & 4.00 & R-MR \\
\hline Sakha 4x NA 112 & 45.67 & 45.67 & 154 & 154 & 41.50 & 40.27 & 112.60 & 62.04 & 1.00 & HR & 1.33 & HR \\
\hline Misr 3 x Nubaria 1 & 51.67 & 51.33 & 154 & 150 & 41.90 & 32.40 & 78.17 & 34.67 & 3.00 & $\mathrm{R}$ & 7.00 & $S$ \\
\hline Misr 3 x Wadi 1 & 39.67 & 40.00 & 154 & 154 & 48.05 & 39.60 & 126.30 & 67.87 & 5.00 & MR & 3.33 & $\mathrm{R}$ \\
\hline Misr 3 x T.W & 39.67 & 39.67 & 157 & 155 & 41.45 & 39.17 & 167.67 & 74.00 & 3.00 & $\mathrm{R}$ & 4.33 & R-MR \\
\hline Misr 3 x NA 112 & 47.00 & 47.00 & 157 & 156 & 38.90 & 32.43 & 59.77 & 73.87 & 3.50 & $\mathrm{R}$ & 4.33 & R-MR \\
\hline Nubaria 1x Wadi 1 & 44.00 & 45.00 & 163 & 162 & 38.85 & 37.47 & 129.20 & 61.80 & 3.00 & $\mathrm{R}$ & 4.00 & R-MR \\
\hline Nubaria 1 x T.W & 50.00 & 50.00 & 163 & 163 & 40.20 & 43.40 & 191.73 & 114.20 & 1.50 & $\mathrm{HR}$ & 3.67 & $\mathrm{R}$ \\
\hline Nubaria 1 x NA 112 & 44.33 & 41.00 & 157 & 157 & 39.00 & 34.40 & 53.83 & 53.00 & 1.50 & HR & 4.33 & R-MR \\
\hline Wadi 1 x T.W & 45.67 & 45.67 & 158 & 158 & 43.50 & 35.77 & 65.67 & 28.47 & 3.00 & $\mathrm{R}$ & 4.33 & R-MR \\
\hline Wadi 1 x NA 112 & 45.00 & 45.00 & 163 & 163 & 46.30 & 39.53 & 48.33 & 48.57 & 3.00 & $\mathrm{R}$ & 3.00 & $\mathrm{R}$ \\
\hline T.W x NA 112 & 91.33 & 91.33 & 168.33 & 167 & 28.50 & 29.60 & 80.77 & 84.90 & 3.00 & $\mathrm{R}$ & 3.67 & R-MR \\
\hline Mean & 49.95 & 49.76 & 157.30 & 156.3 & 41.99 & 35.53 & 96.86 & 68.78 & 3.11 & $\mathrm{R}$ & 3.98 & R-MR \\
\hline Reduction (\%) & \multicolumn{2}{|c|}{0.38} & \multicolumn{2}{|c|}{0.65} & \multicolumn{2}{|c|}{15.39} & \multicolumn{2}{|c|}{28.99} & \multicolumn{4}{|c|}{21.91} \\
\hline LSD' $_{0.05}$ & 2.89 & 2.55 & 0.354 & 0.626 & 1.85 & 2.606 & 1.245 & 1.625 & 1.038 & ------ & 0.537 & ------ \\
\hline
\end{tabular}

HR: Highly resistant R: Resistant MR: Moderately resistant S: Susceptible HS: Highly susceptible 


\section{El-Abssi, et al.}

As presented in Table 2, each of the parental faba bean genotypes Sakha 4 and Misr 3 had the highest mean value of seed weight/plant under the control and the artificial infection conditions. Also, results indicate that the highest value of seed weight/plant was registered in their $F_{1}$ crosses (Sakha 4 x Nubaria 1), (Misr 3 x T.W) and (Nubaria $1 \times$ T.W) under the control condition as well as (Sakha 4 x Misr 3), (Sakha $4 \times$ Wadi 1) and (Nubaria $1 \times$ T.W) under the artificial infection one. Otherwise, the genotype NA 112 gave less mean values of seed weight under the two conditions as well as the $\mathrm{F}_{1}$ cross (Wadi $1 \mathrm{x}$ NA 112) under the control condition and (Wadi $1 \times \mathrm{T} . \mathrm{W})$ under the artificial infection one.

Additionally, all the faba bean parental genotypes except Misr 3, Wadi 1 and crosses ( Sakha 4 x Misr 3), (Sakha 4 x Nubaria 1) and (Misr $3 \times$ Wadi 1) under the natural infection condition as well as the faba bean genotypes i.e., Sakha 4, Nubaria 1, NA 112, ( Sakha 4 x Misr 3), (Sakha 4 x NA 112), (Misr $3 \times$ Wadi 1), (Nubaria $1 \times$ T.W), (Wadi 1 x NA 112) and (T.W $x$ NA 112) under the artificial infection one were considered as highly resistant or resistant to chocolate spot disease, suggesting that these genotypes carry genes for resistance to chocolate spot disease. Similar results were recorded by Abo-Mostafa et al. (2014) and Beyene et al. (2016).

Generally the mean performance of the studied parental faba bean genotypes and their $F_{1}$ crosses for all the studied characters were better under the control and the natural conditions compared with the artificial infection one. These results could be discussed on the basis, that the environmental conditions were more suitable for faba bean under the control and the natural conditions rather than the artificial infection one as biotic stress pressure.

It is of interest to report that the artificial infection condition reduced each of days to flowering by $(0.38 \%)$, days to maturity $(0.65 \%)$, chlorophyll content $(15.39 \%)$, seed weight/plant $(28.99 \%)$ and resistance to chocolate spot (21.91\%) compared with the control and the natural conditions. Thus, incidence of chocolate spot disease reduces plant photosynthetic capacity through metabolic limitations and oxidative damage to chloroplasts, with concomitant reductions in dry matter accumulation and seed yield. Similar conclusion was observed by ElGalaly et al. (2009) and Beyene et al. (2016).

\section{Types of Gene Action, Genetic Ratio and Heritability}

Results given in Table 3 illustrate genetic component of variation and their derived parameters for earliness characters, chlorophyll content, seed weight/plant and resistance to chocolate spot under control, natural and artificial infection by chocolate spot disease. The results revealed that additive (D) and dominance $\left(\mathrm{H}_{1}\right.$ and $\mathrm{H}_{2}$ ) appeared to be significant for all the studied characters under these conditions, revealing the importance of both fixable and non-fixable type of gene action in the inheritance these characters. In this respect, additive and non-additive gene effects were found to be significant with the preponderance of additive gene action in controlling earliness characters and seed weight/ plant Farag and Helal (2004); seed weight/plant Abdalla et al. (2015); days to flowering and seed yield/plant Abou-Zaid et al. (2017).

The additive genetic component was higher in its magnitude as compared to the dominance ones for resistance to chocolate spot under the natural infection condition, resulting in average degree of dominance $\left(\mathrm{H}_{1} / \mathrm{D}\right){ }^{0.5}$ was less than unity. Suggesting that the fixable gene type could exploited efficiently through phenotypic selection. The importance of partial dominance gene effects in controlling this character was also reported by Abo-Mostafa et al. (2014) and Beyene et al. (2016). Whereas, dominance component $\left(\mathrm{H}_{1}\right.$ and $\left.\mathrm{H}_{2}\right)$ made up the most part of the total genetic variation as it is larger in its magnitude than the corresponding additive one for earliness characters, chlorophyll content and seed weight/plant under both conditions. Also, the dominance component $\left(\mathrm{H}_{1}\right)$ was higher in its magnitude than the corresponding additive one for resistance to chocolate spot under the artificial infection only. So, the average degree $\left(\mathrm{H}_{1} / \mathrm{D}\right)^{0.5}$ was more than unity for these characters, confirming the importance of hybrid breeding method for improving these characters. The importance of over-dominance gene effects in controlling these characters was also reported by Ibrahim (2010), Obiadalla-Ali et al. (2013) and Bishnoi et al. (2018). 
Zagazig J. Agric. Res., Vol. 46 No. (6A) 2019

Table 3. Additive (D), dominance $(\mathrm{H})$ genetic variances and their derived parameters for the studied characters under control, natural infection and artificial infection of chocolate spot disease conditions

\begin{tabular}{|c|c|c|c|c|c|c|c|c|c|c|}
\hline \multirow{2}{*}{$\begin{array}{l}\text { Character } \\
\text { Component }\end{array}$} & \multicolumn{2}{|c|}{$\begin{array}{c}\text { Days to flowering } \\
\text { (day) }\end{array}$} & \multicolumn{2}{|c|}{$\begin{array}{c}\text { Days to maturity } \\
\text { (day) }\end{array}$} & \multicolumn{2}{|c|}{$\begin{array}{l}\text { Chlorophyll content } \\
\text { (SPAD) }\end{array}$} & \multicolumn{2}{|c|}{$\begin{array}{l}\text { Seed weight/plant } \\
\text { (g) }\end{array}$} & \multicolumn{2}{|c|}{$\begin{array}{c}\text { Chocolate spot } \\
\text { disease }\end{array}$} \\
\hline & Control & Artificial & Control & Artificial & Control & Artificial & Control & Artificial & Natural & Artificial \\
\hline \multicolumn{11}{|c|}{ Genetic components } \\
\hline D & $385.381^{* * *}$ & $382.048^{* *}$ & $14.146^{*}$ & $12.237^{*}$ & $49.429^{* * *}$ & $38.202^{* *}$ & $2393.972^{* * *}$ & $1454.045^{* * *}$ & $4.547^{* *}$ & $6.189^{* *}$ \\
\hline $\mathbf{H}_{1}$ & $580.636^{*}$ & $618.680^{*}$ & $57.530^{* *}$ & $55.864^{* *}$ & $73.928^{* *}$ & $103.883^{* *}$ & $6669.924^{* *}$ & $3165.212^{* * *}$ & $5.560^{* *}$ & $3.525^{* *}$ \\
\hline $\mathbf{H}_{2}$ & $477.835^{*}$ & $507.279^{*}$ & $49.131^{* *}$ & $48.440^{* *}$ & $67.068^{* *}$ & $82.103^{* *}$ & $5670.133^{* *}$ & $2646.000^{* * *}$ & $3.985^{* *}$ & $2.771^{* *}$ \\
\hline $\mathbf{F}$ & 304.044 & 322.430 & 1.738 & -6.485 & $28.191^{*}$ & $50.085^{*}$ & 1570.744 & 1634.706 & $4.169^{* *}$ & $4.159^{* *}$ \\
\hline $\mathbf{h}^{2}$ & 98.505 & 94.667 & 11.723 & 17.326 & 13.135 & $97.970^{* *}$ & 511.690 & 0.313 & -0.020 & $1.185^{* *}$ \\
\hline $\mathbf{E}$ & 1.360 & 1.037 & 0.021 & 0.063 & 0.229 & 1.063 & 0.287 & 0.426 & 0.196 & 0.053 \\
\hline \multicolumn{11}{|c|}{ Derived parameters } \\
\hline $\mathrm{H} 1 / \mathrm{D}^{\wedge 0.5}$ & 1.227 & 1.273 & 2.017 & 2.137 & 1.223 & 1.649 & 1.669 & 1.475 & 1.106 & 0.755 \\
\hline $\mathrm{H}_{2} / 4 \mathrm{H}_{1}$ & 0.206 & 0.205 & 0.214 & 0.217 & 0.227 & 0.198 & 0.213 & 0.209 & 0.179 & 0.196 \\
\hline KD/KR & 1.947 & 1.992 & 1.063 & 0.779 & 1.608 & 2.320 & 1.489 & 2.231 & 2.416 & 2.605 \\
\hline $\mathbf{h}(\mathbf{n . s})$ & 43.2 & 40.1 & 45.8 & 51.8 & 45.3 & 18.6 & 39.1 & 20.4 & 45 & 65.1 \\
\hline
\end{tabular}

The covariance of additive and dominance gene effects in parents ( $\mathrm{F}$ value) was positive and insignificant for days to flowering and seed weight/plant under the control and the artificial conditions as well as days to maturity under the control one, and significant for chlorophyll content and resistance to chocolate spot under these conditions. This result revealing more frequent of dominant alleles than the recessive ones in the parents for these characters and it was supported by the ratio of $\mathrm{KD} / \mathrm{KR}$, which was more than unity for the previous characters. On the other hand, negative and insignificant $(F$ value) was registered for days to maturity under the artificial infection condition, indicated an excess of recessive alleles in parents, thus, the ratios of $(\mathrm{KD} / \mathrm{KR})$ was low than unity for this character.

The environmental variance was insignificant for all the studied characters under these conditions. The overall dominance effects of heterozygous loci $\left(\mathrm{h}^{2}\right)$ were positive for all studied characters under these conditions except resistance to chocolate spot under the artificial infection condition, hereby, dominance was mainly attributable to heterozygous loci and seemed to be acting in positive direction.

The proportion of genes with positive and negative effects in the parents $\left(\mathrm{H}_{2} / 4 \mathrm{H}_{1}\right)$ were less than its maximum value $(0.25)$ for all the studied characters under control, natural and artificial infection conditions, provide evidence for asymmetrical distribution of positive and negative alleles among the parental populations.

Narrow sense heritability $\left(\mathrm{h}^{2}\right)$ differed in its magnitude, due to the change in the genetic components from the control, natural to the artificial infection of chocolate spot disease. It was high for days to maturity under the artificial infection condition and resistance to chocolate spot under the natural infection one. And moderate for days to flowering under the control and the artificial conditions; days to maturity, chlorophyll content and seed weight/plant under the control condition as well as resistance to chocolate spot under the artificial infection one, suggesting that selection based on phenotype could be effective to improve these characters. 


\section{El-Abssi, et al.}

In this connection, moderate to high narrow sense heritability for these characters were reported by El-Galaly et al. (2009) and Obiadalla-Ali et al. (2013). While, it was low for chlorophyll content and seed weight/plant under the control condition, suggesting that selection for both characters in early generations may not be useful and had to be delayed till late segregating generations. Hence, utilization of heterosis breeding could be rewarding for these characters. In this respect, low narrow sense heritability has been recorded for seed weight/ plant (El-Galaly et al., 2009; Ibrahim, 2010; Ghareeb and Helal, 2014).

\section{REFERENCES}

Abdalla, M.M.F., M.M. Shafik, M.I. Abd ElMohsen, S.R.E. Abo-Hegazy and H.A.M.A. Saleh (2015). Investigation on faba beans, Vicia faba L. 36. heterosis, inbreeding effects, GCA and SCA of diallel crosses of ssp Paucijuga and Eu-faba. J. Ame. Sci., 11 (6): 1-7.

Abdalla, M.M.F., M.M. Shafik, S.M. Attia and H.A. Ghannam (2017). Heterosis, GCA and SCA effects of diallel-cross among six faba bean (Vicia faba L.) genotypes. Asian Res. J. Agric., 4 (4): 1-10.

Abo-Mostafa, R.A.I., E.A.D. Sarhan and Z.E. Ghareeb (2014). Generation mean analysis for disease resistance, yield and its components in three crosses of faba bean (Vicia faba L.). J. Plant Prod., Mansoura Univ., 5 (8): 1375-1390.

Abou-Zaid, G.A., S.M. Mostafa, R.A. El-Refaey and A.M. Mohamed (2017). Estimation of combining ability and hetrosis via half diallel cross in faba bean (Vicia faba L.) for yield, its components and seed quality. J. Plant Prod., Mansoura Univ., 8 (11): 1191-1198.

Al-Ghamdi, S.S. (2007). Genetic behavior of some selected faba bean genotypes. African Crop Sci. Conf. Proc., Minia, Egypt, 8: 709714.

Attia, S.M. and M.M. Salem (2006). Analysis of yield and its components using diallel matings among five parents of faba bean. Egypt. J. Plant Breed., 10 (1): 1-12.
Bernier, C.C., S.B. Hanunik, M.M. Hussein and H.A. Mohamed (1993). Field manual of common faba bean diseases in the Nile Valley. Int. Cent. Agric. Res. Dry Areas (ICARDA) Inform. Bulletin No.3.

Beyene, A.T., J. Derera, J. Sibiya and A. Fikre (2016). Gene action determining grain yield and chocolate spot (Botrytis fabae) resistance in faba bean. Euphytica, 207:293-304

Bishnoi, S.K., J.S. Hooda, P. Sharma and P. Kumar (2018). Analysis of combining ability and inheritance of breeding parameters in yield component traits in faba bean (Vicia faba L.). J. Pharm. and Phytochem., 7(2): 1085-1090.

Bouhassan, A., M. Sadiki and B. Tivoli (2004). Evaluation of a collection of faba bean (Vicia $f a b a$ L.) genotypes originating from the Maghreb for resistance to chocolate spot (Botrytis fabae) by assessment in the field and laboratory. Euphytica., 135: 55-62.

Crop Pro (2019) http://www.croppro.com.au/ crop_disease_manual/bk01-toc.php.

El-Galaly, O.A.M., R.A.I. Abo Mostafa and W.M. El-Rodeny (2009). Evaluation of eight new promising lines of faba bean (Vicia faba L.) for diseases resistance (chocolate spot and rust) and yield In North Delta. Ann. Agric. Sc., Moshtohor, 46 (2):131-140

FAO (2018). Production Year Book, 54, FAO, Rome.

Farag, S.T. and F.A. Helal (2004). Heterosis and combining ability in broad bean (Vicia feba L.). Minufiya J. Agric. Res., 29 (3): 707-722.

Ghareeb, Z.E. and A.G. Helal (2014). Diallel analysis and separation of genetic variance components in eight faba bean genotypes. Ann. Agric. Sci., 59 (1): 147-154.

Hamza, F.E.A. and G.E. Khalifa (2017). The correlation and path coefficient analyses for yield and some yield components of faba bean (Vicia faba L.) genotypes in Northern Sudan. Nile J. Agric. Sci., 2 (1): 52-63.

Hayman, B.I. (1954 a). The theory and analysis of diallel crosses. Genet., 39: 789-809.

Hayman, B.I. (1954 b). The analysis of variance of diallel tables. Biometics, 10: 235-244. 
Ibrahim, H.M. (2010). Heterosis, combining ability and components of genetic variance in faba bean (Vicia faba L.). JKAU: Met., Env. Arid Land Agric. Sci., 21(1):35-50.

Jalal, O.A., R.A. Anwar and A.M. Ribwar (2016). Comparative on yield and its components performance and correlation in some broad bean (Vicia faba L.) genotypes at Bakrajo, Sulaimani. Ame-Eurasian J. Agric. and Environ. Sci., 16 (3): 635-640.

Jinks, J.L. (1954). The analyses of continuous variation in a diallel crosses of (Nieotiana rustica L.) varieties .Genet., 39:767-788.

Leach, R. and K.G. Moore (1966). Sporulation of Botrytis fabae on agriculture. Trans $\mathrm{Br}$ Mycol Soc., 49: 593-601.

Obiadalla-Ali, H.A., E.M.M. Naheif, A.A. Glala and M.H.Z. Eldekashy (2013). Heterosis and nature of gene action for yield and its components in faba bean (Vicia faba L.). J. Plant Breed. and Crop Sci., 5 (3): 34-40

Qabil, N., A.A. Helal and R.Y.S. Abd El-Khalek (2018). Evaluation of some new and old faba bean cultivars (Vicia faba L.) for earliness, yield, yield attributes and quality characters. Zagazig J. Agric. Res., 45 (3): 821-833.

Steel, R.G.D., J.H. Torrie and D.H. Dicky (1997). Principles and Producers of Statistics A. Biometrical Approach $3^{\text {rd }}$ Ed., Mc Graw Hill, New York.

Tivoli, B., D. Berthelem, J. Le Guen and C. Onfroy (1986). Comparison of some methods for evaluation of reaction of different winter faba bean genotypes to Botrytis fabae. FABIS News, 16:46-51. 


\title{
El-Abssi, et al.
}

\section{متوسط السلوك و طبيعة الفعل الجينى للتبكير، المحصول ومرض التبقع الثكولاتى في الفول البلاي}

\author{
مصطفي جمال العبسى - حسن أحمد ربيع - حسن عوده عواد ـ نجلاء قبيل \\ قسم المحاصيل - كلية الزر اعة - جامعة الزقازيق - مصر
}

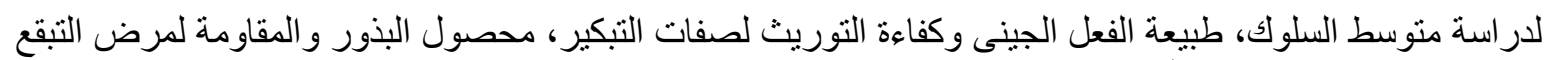

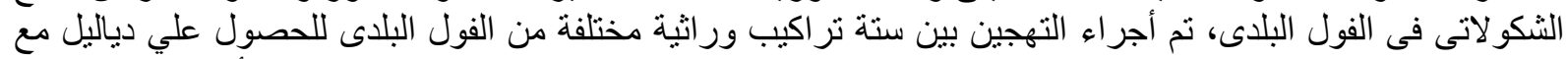

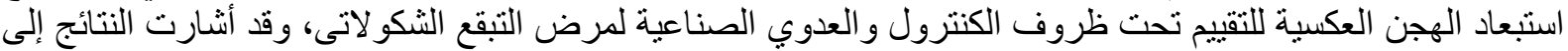

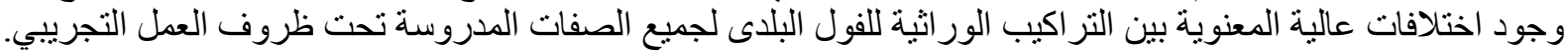

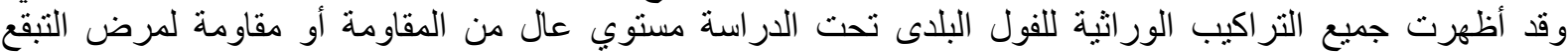

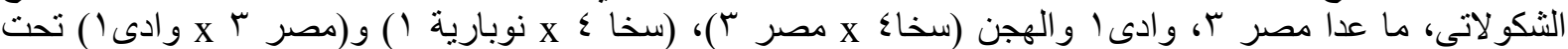

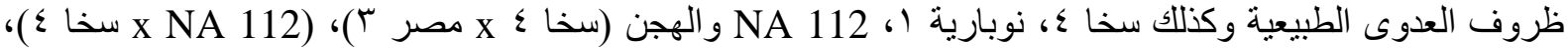

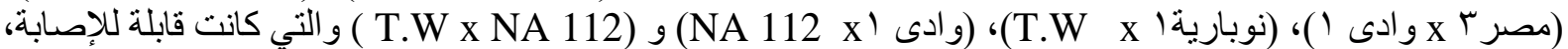

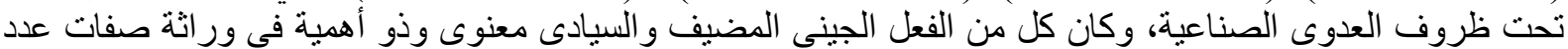

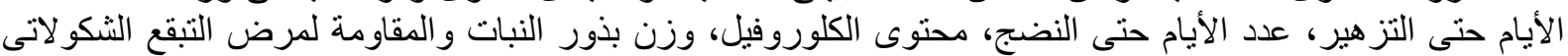

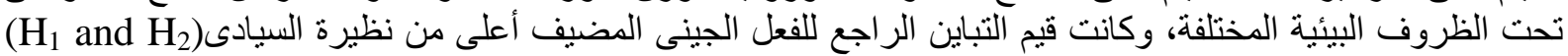

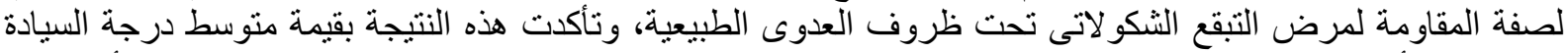

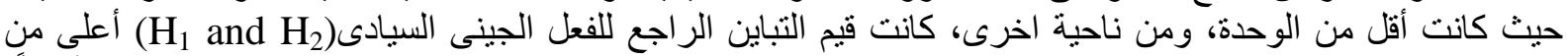

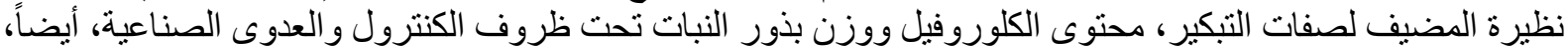

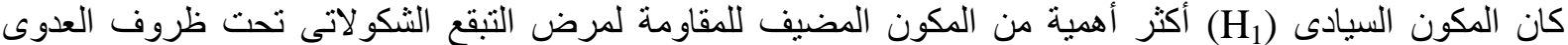

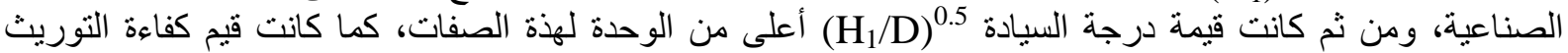

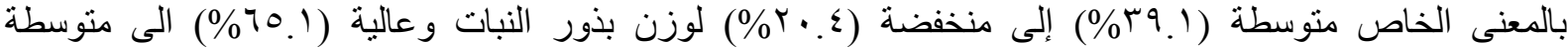

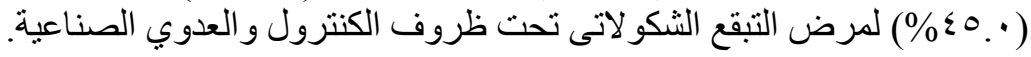

أستاذ المحاصيل ـ كلية الزر اعة بمشتهر - جامعة بنها. أستاذ المحاصيل المساعد ـ كلبة الزراعة الزيلة ـ جامعة الزقازيق.

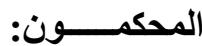

ا ـ أ.د. أحمد على الحصدي

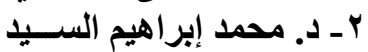

